\title{
Petiveria alliacea extracts uses multiple mechanisms to inhibit growth of human and mouse tumoral cells Claudia Urueña ${ }^{\dagger 1}$, Claudia Cifuentes ${ }^{\dagger 1}$, Diana Castañeda ${ }^{1}$, Amparo Arango ${ }^{1}$, Punit Kaur ${ }^{2,3}$, Alexzander Asea ${ }^{2,3}$ and Susana Fiorentino*1
}

Address: ${ }^{1}$ Grupo de Inmunobiología y Biología Celular, Facultad de Ciencias, Universidad Javeriana, Bogotá, Colombia, ${ }^{2}$ Division of Investigative Pathology, Scott \& White Memorial Hospital and Clinic, Temple, Texas, USA and ${ }^{3}$ The Texas A\&M Health Science Center College of Medicine, Temple, Texas, USA

Email: Claudia Urueña - curuena@javeriana.edu.co; Claudia Cifuentes - ccifuent@javeriana.edu.co;

Diana Castañeda - d.castaneda@javeriana.edu.co; Amparo Arango - amarco_02@yahoo.com; Punit Kaur - pkaur@medicine.tamhsc.edu; Alexzander Asea - asea@medicine.tamhsc.edu; Susana Fiorentino* - susana.fiorentino@javeriana.edu.co

* Corresponding author †Equal contributors

Published: 18 November 2008

BMC Complementary and Alternative Medicine 2008, 8:60 doi:10.1 186/1472-6882-8-60

This article is available from: http://www.biomedcentral.com/1472-6882/8/60

(C) 2008 Urueña et al; licensee BioMed Central Ltd.

This is an Open Access article distributed under the terms of the Creative Commons Attribution License (http://creativecommons.org/licenses/by/2.0), which permits unrestricted use, distribution, and reproduction in any medium, provided the original work is properly cited.
Received: 29 May 2008

Accepted: 18 November 2008

\begin{abstract}
Background: There is ethnopharmacological evidence that Petiveria alliacea can have antitumor activity; however, the mechanism of its cytotoxic activity is not well understood. We assessed multiple in vitro biological activities of an ethyl acetate soluble plant fraction over several tumor cell lines.

Methods: Tumor cell lines were evaluated using the following tests: trypan blue exclusion test, MTT [3-(4,5-dimethylthiazol-2-yl)-2,5-diphenyl tetrazolium bromide], flow cytometry, cytoskeleton organization analysis, cell cycle, mitochondria membrane depolarization, clonogenicity test, DNA fragmentation test and differential protein expression by HPLC-Chip/MS analysis. F4 fraction characterization was made by HPLC-MS.

Results: Petiveria alliacea fraction characterized by de-replication was found to alter actin cytoskeleton organization, induce G2 cell cycle arrest and cause apoptotic cell death in a mitochondria independent way. In addition, we found down regulation of cytoskeleton, chaperone, signal transduction proteins, and proteins involved in metabolic pathways. Finally up regulation of proteins involved in translation and intracellular degradation was also observed.
\end{abstract}

Conclusion: The results of this study indicate that Petiveria alliacea exerts multiple biological activities in vitro consistent with cytotoxicity. Further studies in animal models are needed but Petiveria alliacea appears to be a good candidate to be used as an antitumor agent.

\section{Background}

Inherent or acquired resistance can occur simultaneously to multiple drugs in the majority of tumor cells [1-4]. Almost $40 \%$ of cancer patients with resectable and $80 \%$ with unresectable disease have a reduced response to chemotherapy and radiotherapy. Several mechanisms have been associated with this resistance [5] and in order to overcome it, search for new antitumor agents must target different cell components within the tumor cell. In fact, single antitumoral compounds may be ineffective 
because of their unique molecular target. Therefore, presence of multiple compounds in well characterized plant extract with synergic activities, may tackle this difficulty since agonist or additive functions may emerge.

Petiveria alliacea L. (Phytolaccaceae) is a perennial shrub indigenous to the Amazon Rainforest, although it can grow in areas as Tropical and Central America, Caribbean and Southeastern United States. In folk medicine, Petiveria alliacea, is used to treat a wide variety of disorders. Root in decoction, powder or leaves infusion are used as antispasmodic, antirheumatic (topical use), anti-inflammatory $[6,7]$, antinociceptive [8], hypoglycemiant and abortifacient $[9,10]$. Also there are reports describing the plant with sudorific, anti-venereal, diuretic, sedative, antihelminthic, emmenagogue, anesthetic and depurative $[6,9]$ properties. In some South American countries, alcohol and water infusions have been used in patients with leukemia and breast cancer having good efficacy and reasonable toxicity at higher doses than commonly used by folk medicine [11-13].

Compounds isolated and reported for Petiveria alliacea includes flavonoids as astilbin, myricitrin, engeletin, triterpenes as barbinervic acid, $\alpha$-friedelinol, steroids as daucosterol, lipids as lignoceric acid, nonadecanoic acid, oleic acid, compounds as allantoin, coumarin, [14-16], and several sulfur-containing amino acids in the roots; as well as S-benzylcysteine sulfoxides, and S-(2-hydroxyethyl) cysteine sulfoxides $[17,18]$. It is likely that benzylcysteine sulfoxides serve as precursors to thiosulfinates as S-(2hydroxyethyl)-phenylmethanethiosulfinate and sulfines as thiobenzaldehyde S-oxide. Isolation and identification of three glutamyl dipeptides from roots of this plant have also been reported [19]. Dibenzyl trisulphide (DTS), a lipophilic compound found in the plant and identified as one of the immunomodulatory compounds [20], exhibiting anti-proliferative and cytotoxic activity were the cytoskeleton is implicated [21].

Several reports describe phytochemical characterization of Petiveria alliacea's ethanol and aqueous extracts, $[11,14,16,17,22]$, and ethnopharmacological evidence describing possible antitumor activity [11]. This learning has not been immersed into common medical practice because lack of reliable experimental data. The present study examines cytotoxic activity in vitro of a partially purified Petiveria alliacea fraction over several tumor cell lines. Results warrant to continue toxicological and pharmacological testing that could lead to a role in tumor treatment.

For decades, pharmacognostic and ethnobotanical studies have focused in the search of single plant drug isolation, assuming that one drug is responsible for all plant biolog- ical activity. However, western medicine and even ayurveda, considers the possibility of synergy between different components in phytomedicine. Furthermore, there are clear examples where a single isolated compound is unable to reproduce the plant extract activity [23].

Current technical development in "omics" technology has permitted development of gene expression signatures for plant specific fractions. The latter technical advance allows validation of traditional plant uses, but unfortunately due to the high costs turns to be a technology quite inaccessible for developing countries. The present study, in addition to partial characterization of the plant fraction, we evaluate "protein expression signature" over melanoma tumor cells [24].

\section{Methods \\ Petiveria alliacea fraction preparation}

Plant material was collected in Viota, Cundinamarca, Colombia, and identified by Antonio Luis Mejia (botanical consultant) as Petiveria alliacea Linne. Plant material was compared with the Herbario Nacional Colombiano sample, registry number 333406 of August 12 de 1991. Dry ground leaves and stems ( $300 \mathrm{~g})$ from Petiveria alliacea were extracted under reflux $\left(60^{\circ} \mathrm{C}\right)$ with 1.5 liter of $96 \%$ ethanol for $3 \mathrm{~h}$. The ethanol extract was filtered and evaporated until half its volume. An equal volume of water was added and heated $\left(65^{\circ} \mathrm{C}\right)$ for 20 minutes to allow flocculation. The precipitate was eliminated by filtration and the liquid part subjected to liquid-liquid extraction with ethyl acetate (EtOAc) seven times. All the EtOAc fractions were combined and taken to dryness at $40^{\circ} \mathrm{C}$ under vacuum conditions. The dry extract was submitted to column chromatography on RP-C18 column $(30 \times 4 \mathrm{~cm})$, and mobile phase methanol: water (MeOH: $\mathrm{H}_{2} \mathrm{O}$ ). For ratio (1:1), $600 \mathrm{ml}$ were eluted, yielding F-1 to F3 fractions. F-4 fraction eluted within the first $150 \mathrm{ml}$ of ratio (7:3), and F-5 to F11 fractions eluted from the last $450 \mathrm{ml}$ of ratio $(7: 3)$ and $(9: 1)$. F-1 to F11 fractions were assayed at concentrations ranging from 125 to $1.9 \mu \mathrm{g} / \mathrm{ml}$ but only fraction named F4 exhibited high cytotoxicity causing relevant changes in tumor cell lines morphology, reason why the biological testing was carryout on F4 fraction.

\section{Cell lines and growth conditions}

Mel-Rel was established as a melanoma cell line from tumors developed in REL transgenic mice (gift from Dr. Armell Prevost, Cohin Hospital, Paris, France). A375 are human melanoma cells, courtesy of the Instituto de Investigaciones de la Universidad del Rosario (Bogotá, Colombia) and K562 a human erythroleukemia cell line from ATCC. Cells were placed in RPMI-1640 supplemented medium (10\% FBS, $2 \mathrm{mM}$ L-glutamine, $100 \mathrm{U} / \mathrm{ml}$ penicillin, $100 \mu \mathrm{g} / \mathrm{ml}$ streptomycin, $0.01 \mathrm{M}$ Hepes) and incu- 
bated under humidified environment at $37^{\circ} \mathrm{C}$ and $5 \%$ $\mathrm{CO}_{2}$. Adherent cells at $75 \%$ of confluence were detached (trypsin/EDTA), washed (PBS) and suspended in complete medium. Human peripheral blood mononuclear cells (PBMC) from healthy volunteers were separated by density gradient centrifugation (Ficoll-Hypaque, Amersham, Biosciences) and the human fibroblasts from gingival tissue of healthy volunteers. PBMC and human fibroblasts were suspended in RPMI-1640 supplemented medium (10\% FBS, 2 mM L-glutamine, $100 \mathrm{U} / \mathrm{ml}$ penicillin, $100 \mu \mathrm{g} / \mathrm{ml}$ streptomycin, $0.01 \mathrm{M}$ Hepes) and incubated under humidified environment at $37^{\circ} \mathrm{C}$ and $5 \%$ $\mathrm{CO}_{2}$.

\section{In vitro cytotoxicity (IC50) and normal cell assays}

All tumor cell lines were incubated and treated with F4 fraction (125 to $1.9 \mu \mathrm{g} / \mathrm{ml})$, ethanol $(0.2 \%)$, as negative control and vincristine $(0.1$ to $0.0015 \mu \mathrm{g} / \mathrm{ml})$ as positive control, during $48 \mathrm{~h}$ at $37^{\circ} \mathrm{C}$. Adherent cells trypsinized, and washed with saline phosphate buffer (PBS). Human PBMC and fibroblasts were seeded $\left(2 \times 10^{5}\right.$ cells/well) on 96-well plates and incubated with or without phytohemagglutinin (PHA, GibcoBRL) for $12 \mathrm{~h}$. Afterwards, PBMC and fibroblasts were treated with F4 fraction (125 to $1.9 \mu \mathrm{g} / \mathrm{ml})$, ethanol $(0.2 \%)$ and vincristine, for $60 \mathrm{~h}$ and $24 \mathrm{~h}$, respectively. After treatment cells were centrifuged, F4 fraction removed and lastly cells were carefully washed 3 times (PBS) before adding the MTT. Next $12 \mu \mathrm{l}$ of MTT $12 \mathrm{mM}$ [3-(4,5-dimethylthiazol-2-yl)-2,5-diphenyl tetrazolium bromide] (Molecular Probes, Eugene, Oregon, USA) in PBS was added to each well and incubated for $4 \mathrm{~h}$ at $37^{\circ} \mathrm{C}$. Formazan crystals were dissolved with SDS-HCl $0.01 \mathrm{M}$. MTT results were read at $540 \mathrm{~nm}$ in a Multiskan MCC/340 (LabSystems). In addition cell viability was assessed with a trypan blue dye exclusion test. The IC50 (50\% inhibition of cell growth) value was calculated using Probit analysis (MINITAB ${ }^{\circledast}$ Release 14.1. Minitab Inc. 2003 Statistical Software).

\section{Cell cycle analysis}

Mel Rel, A375 and K562 tumor cells lines, starved for 72 $\mathrm{h}$ (to induce arrest in G1 phase), seeded in 12-well plate $\left(4 \times 10^{5}\right.$ cells/well) were treated with concentrations of F4 fraction at $12,18,24$ and $48 \mathrm{~h}$ under humidified environment at $37^{\circ} \mathrm{C}$ and $5 \% \mathrm{CO}_{2}$. After treatment, cells were washed and fixed with ethanol (70\%, ice-cold) during 18 h. After fixing, cells were suspended in PBS 1X, $100 \mathrm{U} / \mathrm{ml}$ RNase, $50 \mu \mathrm{g} / \mathrm{ml}$ of propidium iodide (Sigma, St. Louis, $\mathrm{MO}$ ) and incubated at room temperature for $30 \mathrm{~min}$. Cell DNA content was measured by flow cytometry using a FACScalibur, (Becton Dickinson, Fullerton, CA). For cytometric data 50,000 cellular events were collected per sample and analyzed with Cell Quest software (Becton Dickinson). Cell cycle distribution percentages are calcu- lated by Modfit LT software. FACScalibur calibration is performed with the DNA QC Particle Kit (Becton Dickinson). Treatments were performed in triplicate, and results express as mean \pm SEM.

\section{Cytoskeleton organization analysis}

A375 human cells $\left(5 \times 10^{4}\right.$ cells $\left./ \mathrm{ml}\right)$ plated on glass coverslides (13 $\mathrm{mm}$ diameter), precoated with collagen (Sigma, St. Louis, MO) were allowed to adhere for $16 \mathrm{~h}$. Afterwards, treated with F4 fraction for $24 \mathrm{~h}$ and incubated under humidified environment, at $37^{\circ} \mathrm{C}$ and $5 \%$ $\mathrm{CO}_{2}$. Treated cells were washed (PBS) and fixed (2\% paraformaldehyde in PBS) for $30 \mathrm{~min}$ at $4{ }^{\circ} \mathrm{C}$. Fixed cells were wash twice with $1 \%$ PBS-BSA, incubated with cold acetone for $1 \mathrm{~min}$, washed (1\% PBS-BSA) and incubated with phalloidin conjugated to Oregon-green (Molecular Probes, Eugene, Oregon, USA), diluted in 1\% PBS-BSA (1/ 40) for $30 \mathrm{~min}$. Slides were mounted with prolong antifade kit (Molecular Probes, Eugene, Oregon, USA) and analyzed under fluorescence microscope (Olympus, Japan).

\section{DNA fragmentation analysis}

A375 human cells were treated and incubated as described on cytoskeleton organization procedures except for last step were cells are stained with $300 \mathrm{nM}$ of DAPI (Sigma, St. Louis, MO) for $5 \mathrm{~min}$. Slides were mounted with prolong anti-fade kit (Molecular Probes, Eugene, Oregon, USA) and cells analyzed under fluorescence microscope (Olympus, Japan).

\section{Clonogenic assays}

K562 human cells $\left(2.5 \times 10^{5}\right.$ cells/well) plated (96-well plate) were treated with $\mathrm{F} 4$ fraction at 31.2, 15.6 and 7.8 $\mu \mathrm{g} / \mathrm{ml}$, or $200 \mu \mathrm{g} / \mathrm{ml}$ etoposide, or $0.1 \mu \mathrm{g} / \mathrm{ml}$ vincristine or $0.2 \%$ ethanol (in PBS) and incubated for $24 \mathrm{~h}$ under humidified environment at $37^{\circ} \mathrm{C}$ and $5 \% \mathrm{CO}_{2}$. After treatment cells were re-plated onto $0.5 \%$ agar dishes $(60-\mathrm{mm}$, 20,000 cells/dish), incubated for 14 days $\left(37^{\circ} \mathrm{C}\right.$ and $5 \%$ $\left.\mathrm{CO}_{2}\right)$ and stained with violet crystal $(0.4 \%$ in ethanol). Cell colonies with more than 50 cells were counted. Treatments were performed in triplicate, and results expressed as mean \pm SEM.

\section{Evaluation of Mitochondrial Membrane potential (MMP)} Mitochondria membrane potential (MMP) was measured on human K562 cells by flow cytometry, using JC-1, a lipophilic cationic probe $\left(5,5^{\prime}, 6,6^{\prime}\right.$-tetrachloro-1, $1^{\prime}, 3,3^{\prime}$ tetraethyl-benzimidazolcarbocyanine iodide), (Sigma, St. Louis, MO). JC-1 (10 $\mu \mathrm{g} / \mathrm{ml}$ in PBS) is added to $3 \times 10^{5}$ cells $/ \mathrm{ml}$ and incubated for $10 \mathrm{~min}$ at $37^{\circ} \mathrm{C}$. Data analysis was processed by Cell Quest software (Becton Dickinson). All treatments were performed in triplicate, and results expressed as mean \pm SEM. 


\section{Characterization and identification of proteins Sample Preparation}

A375 cells treated with F4 fraction $(31.2 \mu \mathrm{g} / \mathrm{ml}$ for $24 \mathrm{~h}$ ) lysed in lysis buffer, supplemented with phosphatase and proteinase inhibitors. Protein samples were de-salted in $10 \mathrm{~K}$ microcon, diluted with $100 \mathrm{ml}$ of ammonium bicarbonate buffer $(100 \mathrm{mM})$. Cysteine residues were reduced with DTT $(10 \mathrm{mM})$ by incubation at $65^{\circ} \mathrm{C}$ for $45 \mathrm{~min}$. After cooling to room temperature, sulfhydryls were alkylated with iodoacetamide $(55 \mathrm{mM})$ for $30 \mathrm{~min}$ at room temperature in a dark environment. The reduced and alkylated sample was diluted (1:1) with water. Trypsin (Promega, Madison, WI) was added at a 1:50 enzyme:substrate ratio, and incubated overnight at $37^{\circ} \mathrm{C}$. Tryptic peptides were completely dried in a SpeedVac and reconstituted with $10 \mathrm{ml}$ of $0.1 \%$ TFA.

\section{HPLC-Chip/MS analysis}

A $1 \mathrm{ml}$ sample of peptides was injected onto an LC/MS system consisting of an 1100 Series liquid chromatograph, HPLC-Chip Cube MS interface, and 1100 Series LC/MSD Trap XCT Ultra ion trap mass spectrometer (all Agilent Technologies). The system is equipped with an HPLC-Chip (Agilent Technologies) that incorporated a 40-nl enrichment column and a 43- $\mathrm{mm} \times 75-\mathrm{mm}$ analytical column packed with Zorbax 300SB-C18 5-mm particles. Peptides were loaded onto the enrichment column with $97 \%$ solvent A (water with $0.1 \%$ formic acid). They were then eluted with a gradient from 3\% B (acetonitrile with $0.1 \%$ formic acid) to $45 \%$ B in $25 \mathrm{~min}$, followed by a steep gradient to $90 \% \mathrm{~B}$ in $5 \mathrm{~min}$ at a flow rate of $0.3 \mathrm{ml} /$ min. The total runtime, including column reconditioning, was $35 \mathrm{~min}$. The column effluent was directly coupled to an LC/MSD Trap XCT Ultra ion trap mass spectrometer (Agilent Technologies) via a HPLC-Chip Cube nanospray source operated at $\sim 1900$ volts in ultra-ultra mode. The gain control (ICC) was set to 500000 with a maximum accumulation time of 150 milliseconds. CID was triggered on the six most abundant, not singly charged peptide ions in the $\mathrm{m} / \mathrm{z}$ range of 450-1500. Precursors were set in an exclusion list for $1 \mathrm{~min}$ after two MS/MS spectra.

\section{Data analysis}

CID data was searched against the SwissProt all species database, using the Agilent Spectrum Mill Server software (Rev A.03.03.) installed on a HP Intel ${ }^{\circledR}$ Xeon (TM) dual processor server. Peak lists were created with the Spectrum Mill Data Extractor program with the following attributed: scans with the same precursor $\pm 1.4 \mathrm{~m} / \mathrm{z}$ were merged within a time frame of $\pm 15 \mathrm{~s}$. Precursor ions needed to have a minimum signal to noise value of 25. Charges up to a maximum of 7 were assigned to the precursor ion, and the 12C peak was determined by the Data Extractor. The SwissProt database was searched for tryptic peptides with a mass tolerance of $\pm 2.5 \mathrm{Da}$ for the precursor ions and a tolerance of $\pm 0.7 \mathrm{Da}$ for the fragment ions. Two missed cleavages were allowed. A Spectrum Mill auto-validation was first performed in the protein details, followed by peptide mode using default values [Minimum scores, minimum scored peak intensity (SPI), forward minus reversed score threshold, and rank 1 minus rank 2 score threshold]. All protein hits found in a distinct database search by Spectrum Mill were non-redundant. Analysis of the increase or decrease in proteins was performed by comparing each sample with the control. Those values above and below 0.250 from the control value were considered up- or down-regulated.

\section{HPLC-PDA MALDI-TOF}

HPLC chromatogram was recorded on a Waters HPLC Alliance 2690 (Waters, Milford, MA) chromatograph with PDA detector (Waters 2690), and RP-C18 column (5 $\mu \mathrm{m}$, $2.1 \times 150 \mathrm{~mm}$, Waters $)$, at $0.3 \mathrm{ml} / \mathrm{min}$ with acetonitrilewater (4:6). MALDI-TOF spectra was recorded in a mass spectrometer (Bruker Reflex III), equipped with a $337 \mathrm{~nm}$ $\mathrm{N}_{2}$ laser and HCCA matrix.

\section{Statistical analysis}

The mean fluorescent intensity was used to compare flow cytometry data of controls and samples and expressed as the mean \pm SEM. The unpaired Student's $t$-test was used ( $\mathrm{p}$ $<0.05)$ to measure differences between treatments and controls. IC50 was estimated using Minitab 14 Statistical Software Probit analysis [(MINITAB ${ }^{\circledast}$ Release 14.1. Minitab Inc. 2003 Statistical Software).

\section{Results \\ F4 fraction Characterization}

Fig. 1A shows 7 peaks. Peak 2 and 3 accounts for approximately $60 \%$ of total area. Maximum absorption $\lambda$ (lamda) for peak 2 is $278 \mathrm{~nm}$, and for peak 3, 266 and 319 nm. Peak 6 accounts for $12 \%$ of the total area, with maximum absorption $\lambda$ at $284 \mathrm{~nm}$. Peaks 1, 4, 5 and 7 independently, exhibit lower percentages, but combined account for $27 \%$ of the total fraction. Peaks maximum absorption $\lambda$ are 279, 285, 317 and $316 \mathrm{~nm}$, respectively. Fig. 1B shows F4 fraction mass spectra profile including 10 peaks with the following mass/charge $(\mathrm{m} / \mathrm{z})$ ratios: $140,193,206,213,219,272,329,340,369$, and 468. The HCCA peaks correspond to matrix (4-cyano-4 hydroxycinnamic acid) signals. Peaks with $\mathrm{m} / \mathrm{z}$ of 340 and 369 have the higher concentrations, while peaks of $\mathrm{m} / \mathrm{z}$ ratios 140,193 and 206 reveal intermediate concentrations. Peaks with $\mathrm{m} / \mathrm{z}$ ratios of $213,219,272,329$ and 468 have the lowest concentrations. Fig. 1C shows possible compounds present in $\mathrm{F} 4$ fraction with their corresponding molecular masses. Compound identification accomplish by matching the MALDI-TOF $\mathrm{m} / \mathrm{z}$ with molecular weights of compounds previously reported for Petiveria [14$17,22]$. The $\mathrm{m} / \mathrm{z}$ ratio given by MALDI-TOF spectra comprises a deviation range of \pm 7 mass units, due to the method used. This difference was taken into account for 
A

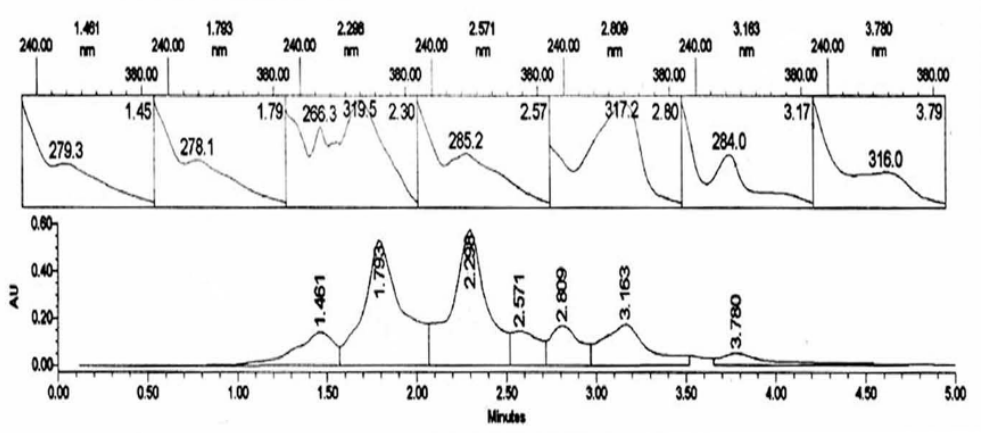

B

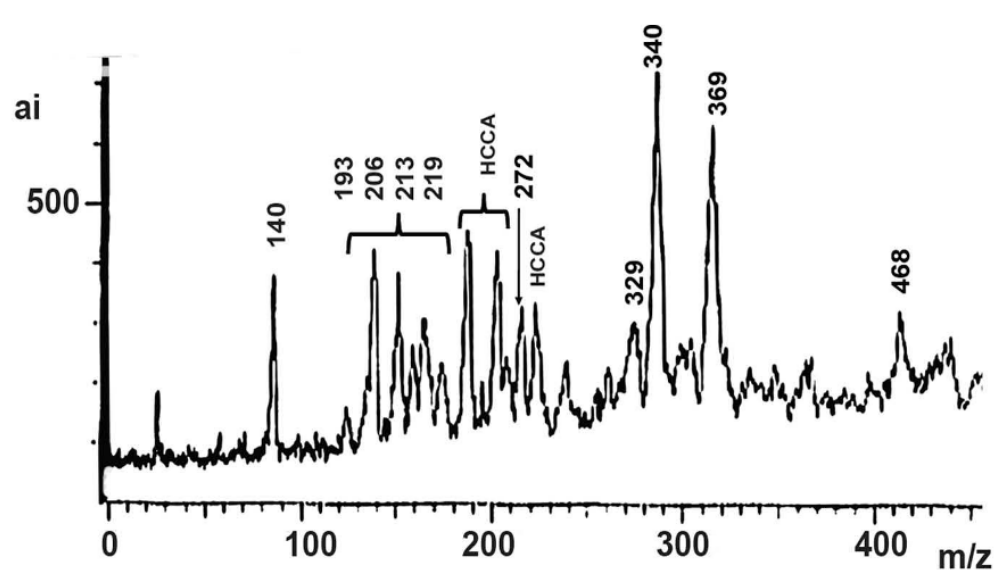

C

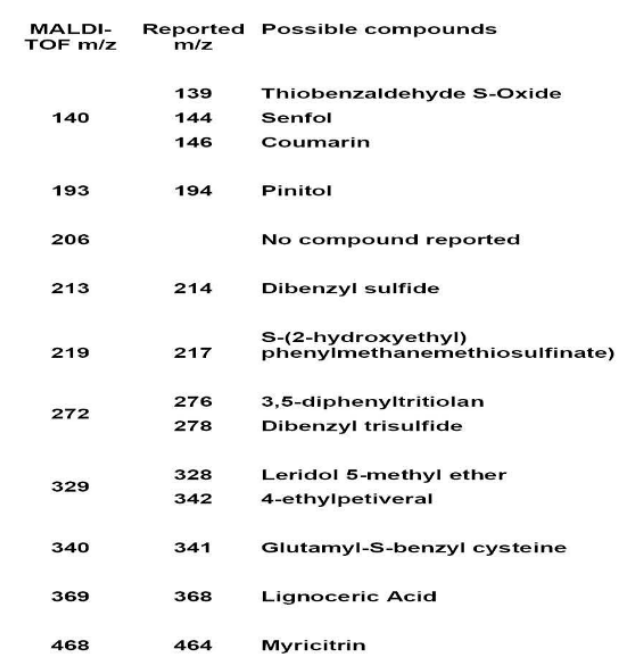

Figure I

Petiveria alliacea F4 fraction characterization. A. Upper panel shows compound UV spectra and retention time. Lower panel shows peak area and retention time. B. F4 fraction was subjected to MALDI-TOF-MS analysis. Numbers above the peaks correspond to $\mathrm{m} / \mathrm{z}$ ratios. The horizontal axis represents the mean relative intensity and the abscissa $\mathrm{m} / \mathrm{z}$ ratios. HCCA peaks correspond to matrix (4-cyano-4 hydroxy-cinnamic acid) signals. C. $\mathrm{m} / \mathrm{z}$ ratio of compounds reported for Petiveria and compounds found in F4 fraction matching within $( \pm 7)$ units of the $\mathrm{m} / \mathrm{z}$ ratio. 
compound identification. The observed peak $(\mathrm{m} / \mathrm{z}=140)$ represents three possible compounds: thiobenzaldehydeS-oxide, 1,2 diisothiocyanato ethane (senfol) and coumarin, with molecular masses of 139, 144 and 146 respectively. The peak of $\mathrm{m} / \mathrm{z}=193$ probably corresponds to pinitol (194), and peak 206, no compounds matching that $\mathrm{m} / \mathrm{z}$ ratio are reported for Petiveria alliacea. Peaks with $\mathrm{m} / \mathrm{z}$ of 213,219 and 272 respectively, correspond to sulfur compounds: dibenzyl sulfide, S-(2-hydroxyethyl)phenylmethanethiosulfinate and for peak 272 two compounds; 3,5-diphenyltritiolan (276) and dibenzyltrisulfide (278). A m/z of 329 corresponds to flavonoid 5-Omethyl leridol, while a $\mathrm{m} / \mathrm{z}$ of 340 has two possible compounds 4-ethyl petiveral and glutamyl-S-benzyl cysteine. Finally peaks 369 and 468 correspond to lignoceric acid and myricitrin respectively. Since compound identification was carry out comparing $\mathrm{m} / \mathrm{z}$ ratio calculated by MALDI-TOF with the reported $\mathrm{m} / \mathrm{z}$ ratios, identification of stereoisomers by this approach is not feasible. Based on $\mathrm{m} / \mathrm{z}$ ratios, the compounds described for the $\mathrm{F} 4$ fraction are thought to be those presented. However, definitive identification is underway.

\section{Petiveria alliacea F4 fraction induces morphological changes on tumor cell lines without affecting normal human cells}

F4 fraction cytotoxic activity evaluated by MTT assay is shown on figures $2 \mathrm{~A}, \mathrm{~B}$ and $2 \mathrm{C}$. The cytotoxicity of F4 fraction is dose dependent inducing significant morphological changes, as cell deformation and elongation in similar way to vincristine in all tested tumor cell lines (Fig. 3A). According to IC50, F4 fraction shows similar cytotoxic potency on A375, Mel Rel and K562 tumor cells lines with values of $35,2,36,3$ and $32,0 \mu \mathrm{g} / \mathrm{ml}$ respectively (Table 1 ). Comparing cytotoxic activity between tumor cell lines and normal human cells, F4 fraction exhibits significantly less cytotoxicity on normal fibroblasts (IC50 $440 \mu \mathrm{g} / \mathrm{ml}$ ) (Fig. 2D and Table 1) or human mononuclear cells with or without phytohemaglutinin (PHA) (IC50 151, $121 \mu \mathrm{g} / \mathrm{ml}$ respectively) (Fig. 2E, F and Table 1). F4 fraction is by far the most promising fraction owing significant difference in cytotoxicity for tumor cell lines as compared with normal cells, explaining the reason why F4 fraction was extensively studied.

In addition, we observed that tumor cells treated with F4 fraction underwent morphological changes in shape, adhesion ability and induced G2 phase arrest. To further study F4 fraction activity on actin cytoskeleton organization, cells treated with F4 fraction were stained with phalloidin-oregon green conjugate. As observed in Fig. 3B, actin cytoskeleton organization was disturbed after 24 hours. A375 cells treated with F4 fraction did not show the same fluorescence pattern as observed in control cells (ethanol $0.2 \%$ ). Vehicle cells showed considerable F-actin cytoskeleton organization (Fig. 3B; left panel), while cells treated with F4 fraction showed differences in shape, displaying reorganized filamentous structures (Fig. 3B; middle and right panels). The latter indicates that actin filaments were transformed into actin granules confining at the cell sub-membrane area. Similar results were obtained with cell line Mel-Rel (data not shown).

\section{F4 fraction induces apoptosis in a mitochondria independent way}

Antitumor drugs commonly induce apoptosis via mitochondria, liberating cytochrome $\mathrm{c}$, activating endonucleases, and ending in DNA fragmentation. However, F4 fraction did not induce mitochondrial membrane depolarization in K562 cells, contrasting with the behavior shown by S2 fraction (positive control used), which is also a Petiveria alliacea fraction that induces mitochondrial depolarization (Fig. 4A). Nonetheless, F4 fraction instead stimulates endonuclease activation and DNA fragmentation shown by staining with DAPI and analyzed by fluorescence microscopy on A375 cells (Fig. 4B). This suggests that F4 fraction activates effector caspases in a mitochondria independent pathway.

\section{Effect of F4 fraction on tumor cell cycle distribution}

To further study the effect of F4 fraction on tumor cell lines, cell cycle distribution was assessed on A375, K562, and Mel-Rel cell lines by flow cytometry, staining the DNA content with propidium iodide. Cells treated with a single dose of F4 fraction $(31.2 \mu \mathrm{g} / \mathrm{ml})$ induced G2 arrest $(60 \%)$ as compared with a negative control (18\%) ethanol $(0.2 \%)$. Vincristine $(0.1 \mu \mathrm{g} / \mathrm{ml})$, positive control induced G2 arrest (80\%) as shown on Fig. 5A. K562 and Mel Rel behave in the same manner (data not shown). In addition, F4 fraction activity over cell cycle kinetics was further investigated, by synchronizing A375 cells in a pulse chase experiment over $48 \mathrm{~h}$. The G2 arrest in A375 cells lasts $48 \mathrm{~h}$ as shown in Fig. 5B. The G2 arrest was pro-

Table I: Comparative IC50 values of F4 fraction and vincristine over tumor cell lines and normal human cells.

\begin{tabular}{ccccccc}
\hline CELLS & A375 & K562 & Mel Rel & PBMC no PHA & PBMC with PHA & Fibroblasts \\
\hline F4 fraction $(\mathrm{IC50} \mu \mathrm{g} / \mathrm{ml})$ & $35.2 \pm 1.35^{*}$ & $32 \pm 1.41$ & $36.3 \pm 1.64$. & $121 \pm 2.6^{*}$ & $151 \pm 8.3 *$ \\
Vincristine $(\mathrm{IC50} \mathbf{\mathrm { MM }})$ & $132 \pm 10^{*}$ & $61 \pm 4^{*}$ & $124.5 \pm 15^{*}$ & $247 \pm 22^{*}$ & $440 \pm 15^{*}$ \\
\hline
\end{tabular}

$\pm=$ SEM, $p<0.05$

The IC50 values of tumor cell lines and normal human cells treated with F4 fraction were calculated with Minitab I4 Statistical Software Probit analysis. The values are mean \pm SEM from three independent experiments. 
A

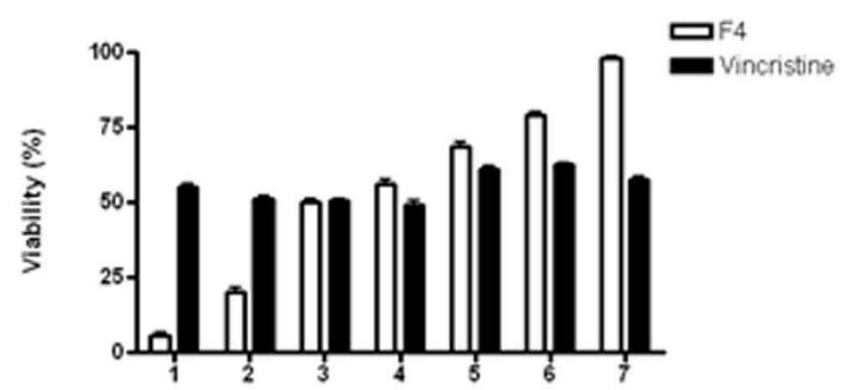

Concentration $(\mu \mathrm{g} / \mathrm{ml})$

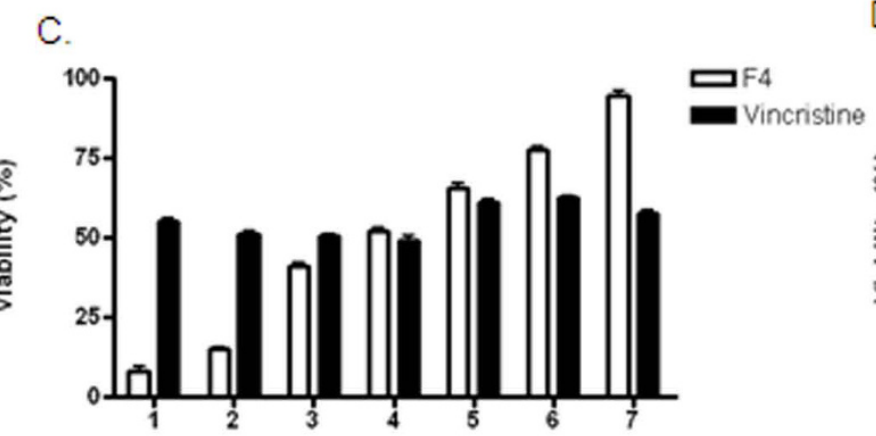

Concentration $(\mu \mathrm{g} / \mathrm{ml})$

E.

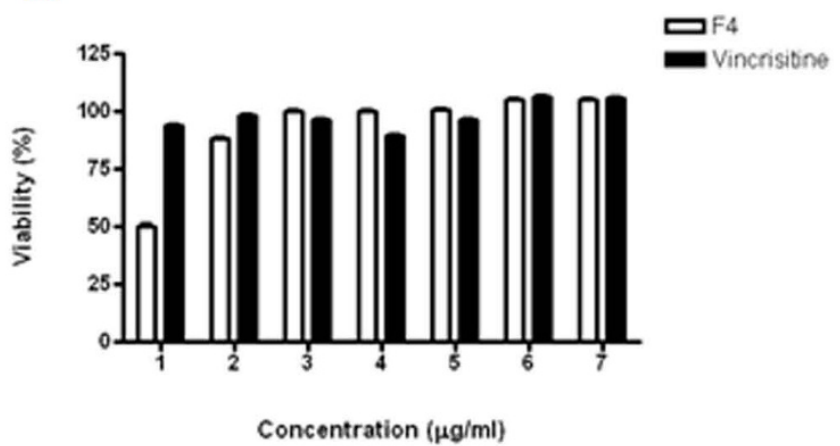

B.

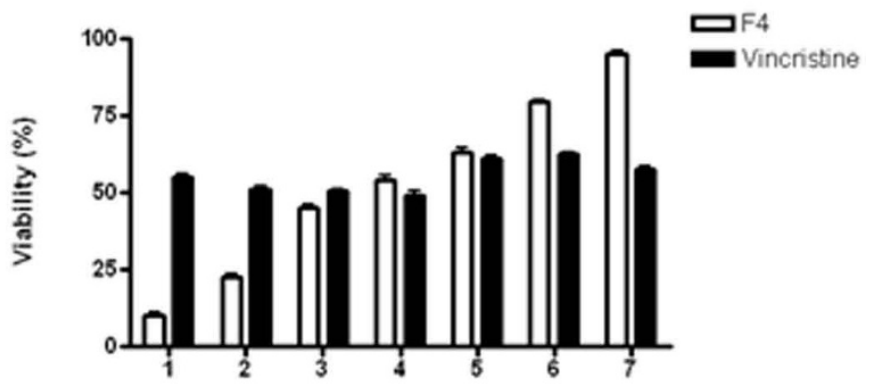

Concentration ( $\mu \mathrm{g} / \mathrm{ml})$

D.

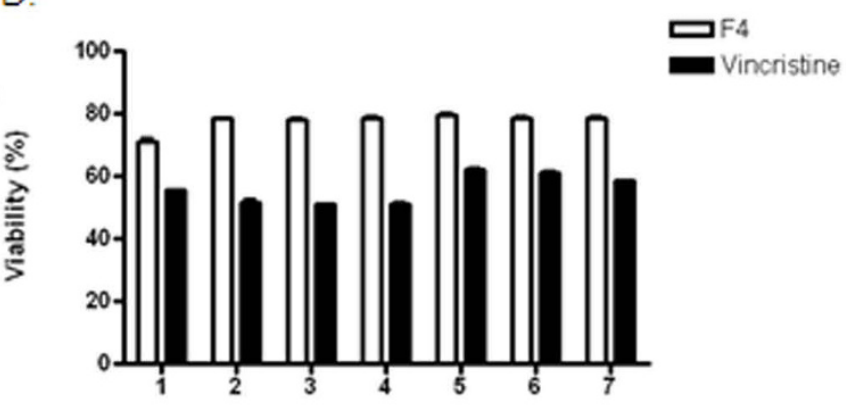

Concentration $(\mu \mathrm{g} / \mathrm{ml})$

F.

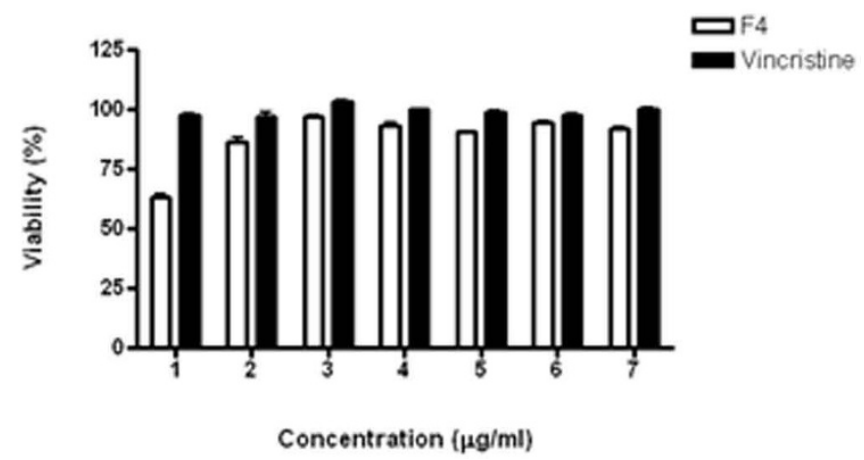

Figure 2

Petiveria alliacea F4 fraction is cytotoxic to tumor cell lines without affecting human normal cells. A. A375 B. Mel Rel C. K562 D. Human fibroblasts E. PBMC stimulated with PHA or F. PBMC-PBS treated with F4 fraction concentrations (white) at I 25 (I), 62.5 (2), 3 I.2 (3), I 5.6 (4), 7.8 (5), 3.9 (6), and I.8 $\mu \mathrm{g} / \mathrm{ml}$ (7); or vincristine (black) $0 . \mathrm{I}$ (I), 0.05 (2), 0.025 (3), 0.0125 (4) $0.00625(5), 0.003 \mathrm{I}(6)$ and $0.0015 \mu \mathrm{g} / \mathrm{ml}(7)$, for $24 \mathrm{~h}$. Cell viability was determined by MTT assay as described in the methods section. Data represent cell viability percentage (\%), where the vehicle-treated cells are regarded as $100 \%$. The values are mean \pm SEM from three independent experiments.

duce at 31.2 and $15.6 \mu \mathrm{g} / \mathrm{ml}$ but not at higher concentrations (Fig. 5C).

\section{F4 fraction reduces tumor cells clonogenic survival}

K562 human cell line treated with F4 fraction significantly reduced cell colony formation, as compared with vehicle cells $(0.2 \%$ ethanol). Colonies were evaluated after 14 days of treatment (Fig. 6) and a decrease in clonogenic survival was observed in treated cells as compared to a negative control $(0.2 \%$ ethanol). However, the decrease in clonogenic survival exhibited by positive controls, etoposide $(100 \mu \mathrm{g} / \mathrm{ml})$ and vincristine $(0.1 \mu \mathrm{g} / \mathrm{ml})$ was slightly greater. Similar data was observed on A375 cells (data not shown). 
A

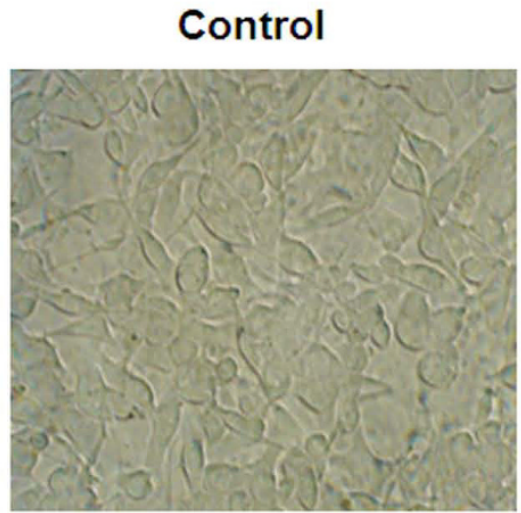

Control

B

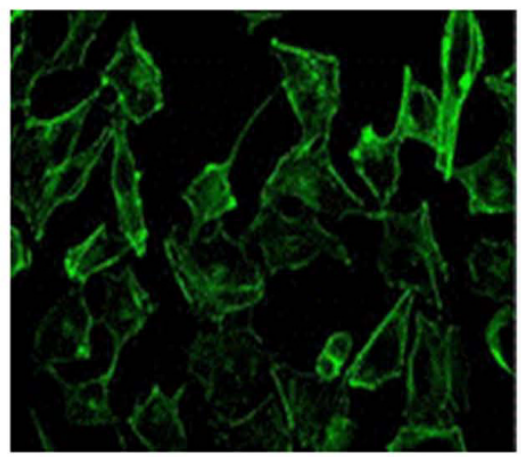

Vincristine

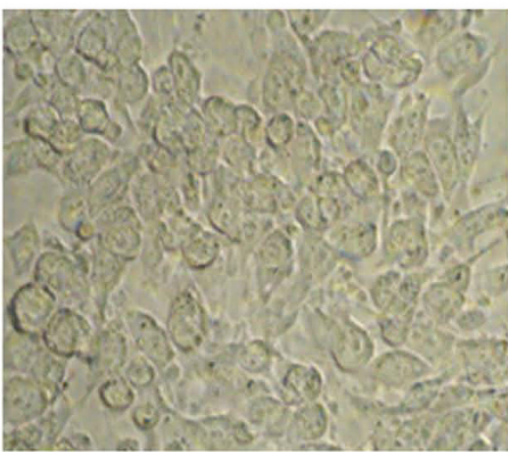

F4

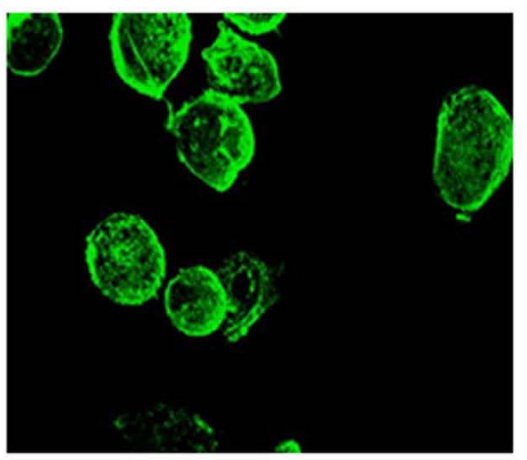

F4
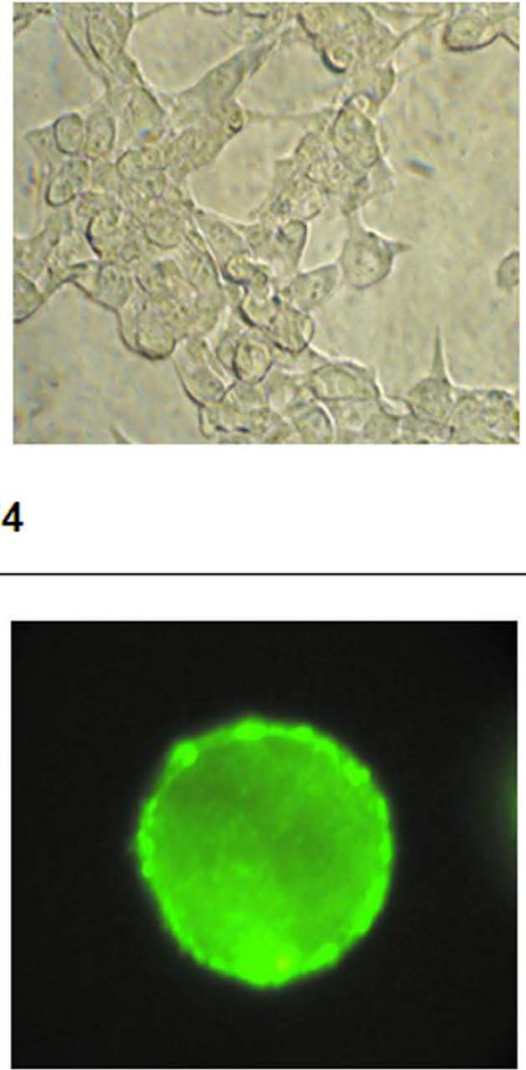

Figure 3

F4 fraction induces morphological changes in tumor cells. A. A375 cells treated with ethanol $0.2 \%$ (left panel), vincristine $0.1 \mu \mathrm{g} / \mathrm{ml}$ (middle panel) or F4 fraction $31.2 \mu \mathrm{g} / \mathrm{ml}$ (right panel). Morphological changes were analyzed under invert microscope. Results represent three independent performed experiments. B. A375 (104) treated with ethanol $0.2 \%$ (left panel) or F4 fraction $31.2 \mu \mathrm{g} / \mathrm{ml}$ (middle and right panels) for $24 \mathrm{~h}$. Cells were stained with Oregon Green-phalloidin were analyzed under fluorescent microscope. Results show photos representing four independent experiments.

\section{Proteomic characterization of F4 fraction activity over tumor cells}

To better understand the mechanism by which F4 fraction exerts its cytotoxic activity on tumor cell lines, A375 (human) cells were treated with F4 fraction (15 and 31.2 $\mu \mathrm{g} / \mathrm{ml}$ ) or ethanol $(0.2 \%)$ (negative control) for 24 hours. The protein content was analyzed by mass spectrometry. Experimental analysis demonstrated that various proteins were either up- or down-regulated (Table 2 and 3 ). Out of 201 proteins 76 were up-regulated, 114 were down-regulated and 11 remained unchanged. Ribosomal proteins (e.g., ribosomal protein L4, 5, 7a, 8, 9, 10, 10a, 11, 12, 13, 14, 18, 18a, 19, 23, 26, 27, 27a, 28, 32, 36, 37a, ribosomal protein S2, 4, 5, 6, 8, 11, 12, 13, 15a, 18, 19, 24, 25, 27, 31 and ribosomal protein P0 variant) are molecules important for tumor growth and survival. Cytoskeleton proteins (e.g., lamin B1, dynein light chain 1, plectin, tcomplex polypeptide 1 (TCP-1), chaperonin containing
TCP-1 (subunit $6 \mathrm{~A}$ and 7), kinesin, tubulin alpha 6, myosin heavy polypeptide 9, actin, gamma 1 propeptide, adenylyl cyclase-associated protein, F-actin capping protein alpha 1, Miller-Dieker lissencephaly protein, myosin, light polypeptide $6 \mathrm{~B}$, alkali, smooth muscle and nonmuscle, (isoform CRA) are also down-regulated.

Efficiency in synthesis of cytoskeleton proteins is required for tumor colony formation, partly explaining why treatment with F4 cells cannot form colonies in soft agar. In addition, these results explain why morphology of treated cells is also abhorrent under light microscope. Also treatment of tumor cell lines with F4 fraction affected proteins associated with metabolism (e.g., peroxiredoxin 6, glucose phosphate isomerase, ACLY variant protein, phosphoglycerate dehydrogenase, pyruvate kinase, muscle isoform CRA, enolase 1, variant Fatty acid synthase, lactate dehydrogenase $\mathrm{A}$, phosphoglicerate kinase (PGK), 


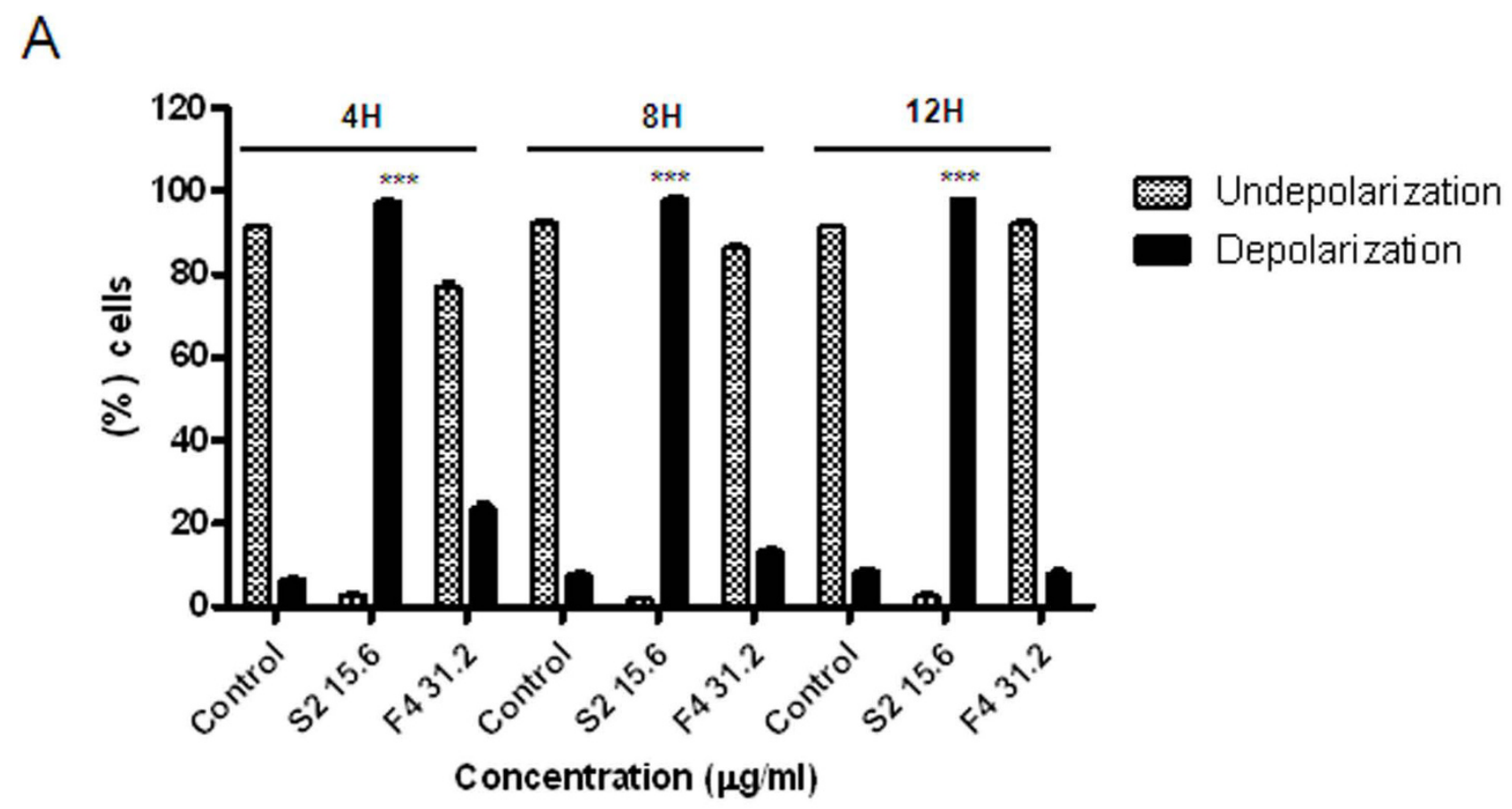

Control

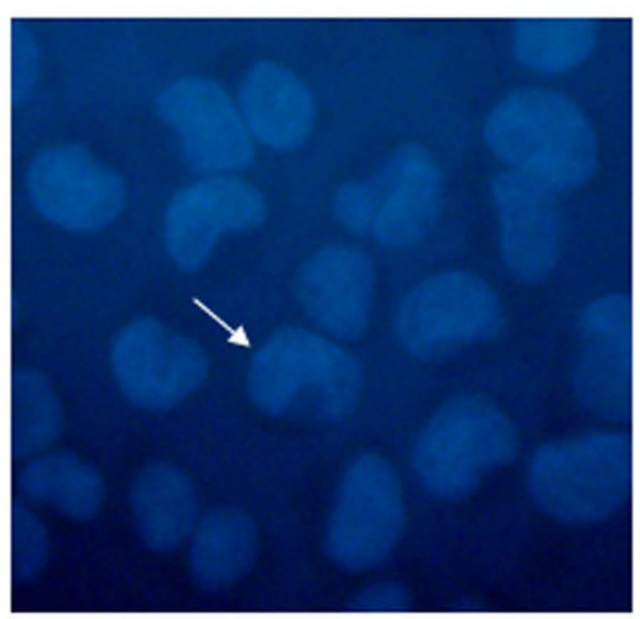

F4

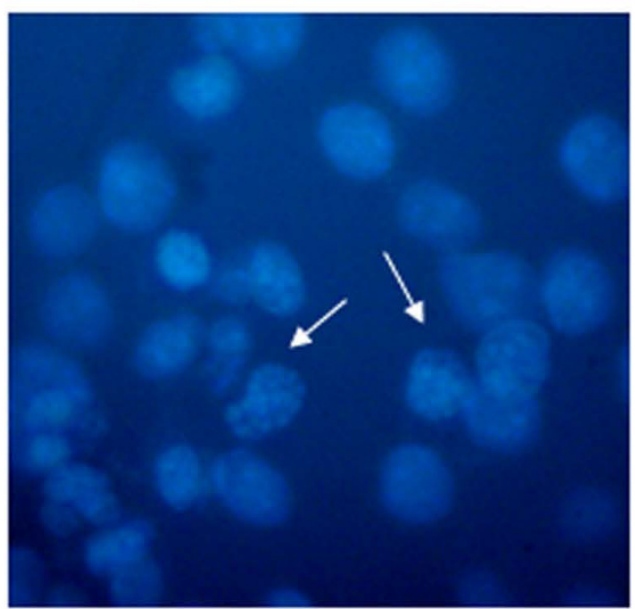

\section{Figure 4}

F4 fraction has no activity on mitochondrial membrane depolarization. A. K562 human cells were treated with F4 fraction $(31.2 \mu \mathrm{g} / \mathrm{ml})$, or positive control S2 fraction $(15.6 \mu \mathrm{g} / \mathrm{ml})$ or ethanol $(0.2 \%)$ for 4,8 and I 2 h. All cells were stained with JC-I (Sigma) dye and analyzed by flow cytometry (FACScalibur CellQuest software program) (Becton Dickinson). Bars represent cell percentage (\%) \pm SEM of depolarized (filled bars) or non-depolarized (hatched bars) cells, representing two independent experiments. ${ }^{* * *} p<0.00$ I versus control (ethanol $0.2 \%$; Unpaired Student's $t$-test). B. A375 cells treated with ethanol $(0.2 \%)$ (left panel) or F4 fraction $(31.2 \mu \mathrm{g} / \mathrm{ml})$ (right panel) for $24 \mathrm{~h}$ were permeabilized, stained with DAPI and analyzed under fluorescence microscope (Olympus). Results show photos representing four independent experiments. 
A
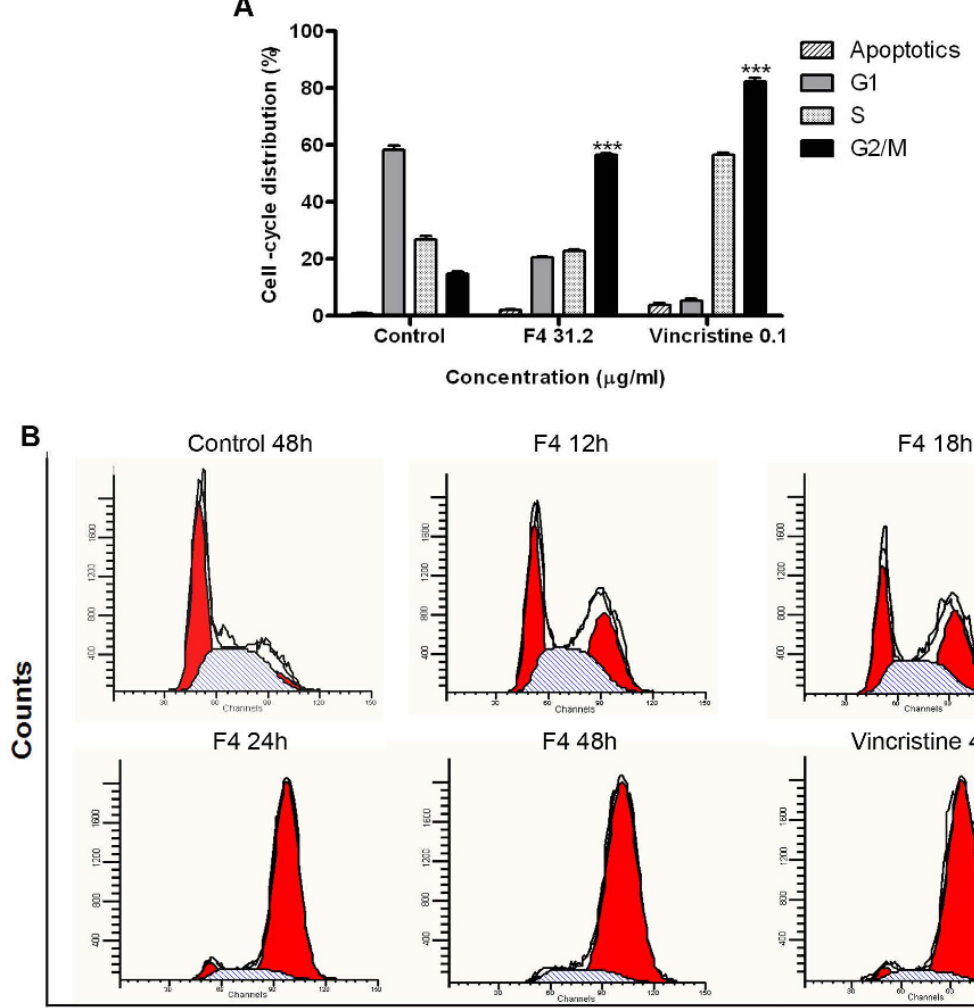

F4 12h

F4 18h
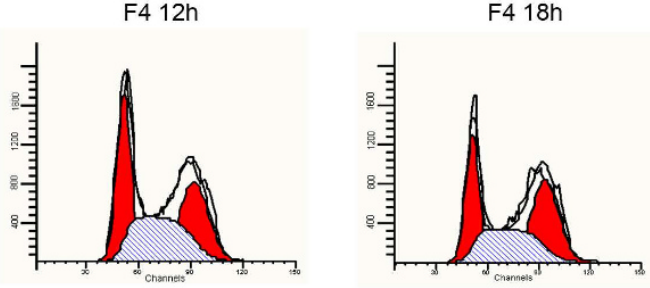

F4 48h

Vincristine $48 \mathrm{~h}$
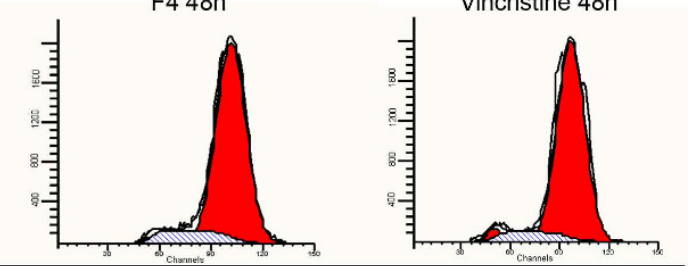

PI

C
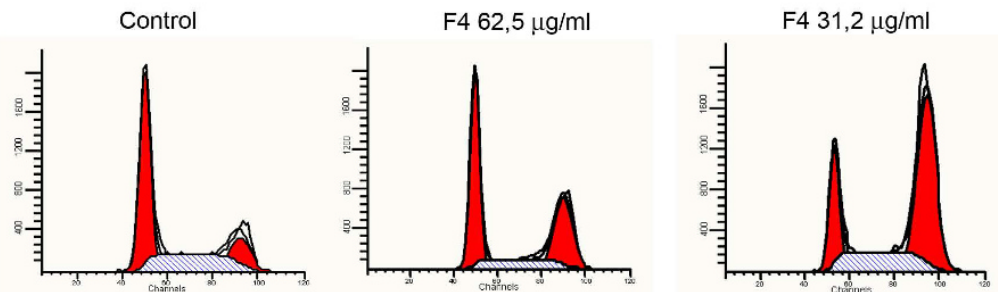

F4 $15,6 \mu \mathrm{g} / \mathrm{ml}$

Vincristine $0,1 \mu \mathrm{g} / \mathrm{ml}$
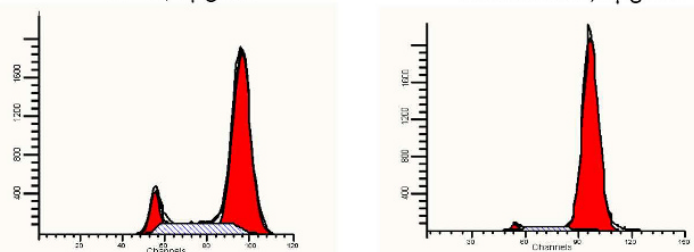

PI

\section{Figure 5}

Effect of Petiveria alliacea F4 fraction on cell cycle. A. A375 cells treated with ethanol ( $0.2 \%)$, or F4 fraction ( $3 \mathrm{I} .2 \mu \mathrm{g} / \mathrm{ml})$ or vincristine $(0.1 \mu \mathrm{g} / \mathrm{ml})$ for $24 \mathrm{~h}$, were permeabilized, stained with propidium iodide $(\mathrm{PI}) 50 \mu \mathrm{g} / \mathrm{ml}$ and analyzed through flow cytometry (FACScalibur CellQuest software program) (Becton Dickinson). Bars represent relative percentage of cell-cycle distribution \pm SEM and represent three independent performed experiments. $* * * p<0.00 \mathrm{I}$ versus control (ethanol $0.2 \%$;

Unpaired Student's $t$-test). B. A375 cells treated with ethanol $(0.2 \%)$ or F4 fraction $(31.2 \mu \mathrm{g} / \mathrm{ml})$ or vincristine $0.1 \mu \mathrm{g} / \mathrm{ml}$ for 12 , 18,24 and $48 \mathrm{~h}$, were permeabilized, stained with PI $50 \mu \mathrm{g} / \mathrm{ml}$ and analyzed through flow cytometry (FACScalibur CellQuest software program) (Becton Dickinson). Histograms represent relative cell DNA content representing two independent experiments. C. A375 cells treated with ethanol $(0.2 \%)$ or F4 fraction $(62.5,31.2,15.6 \mu \mathrm{g} / \mathrm{ml})$ or vincristine $(0.1 \mu \mathrm{g} / \mathrm{ml})$ for $48 \mathrm{~h}$, were permeabilized, stained with PI $50 \mu \mathrm{g} / \mathrm{ml}$ and analyzed through flow cytometry (FACScalibur CellQuest software program) (Becton Dickinson). Histograms represent relative cell DNA content representing two independent experiments. 


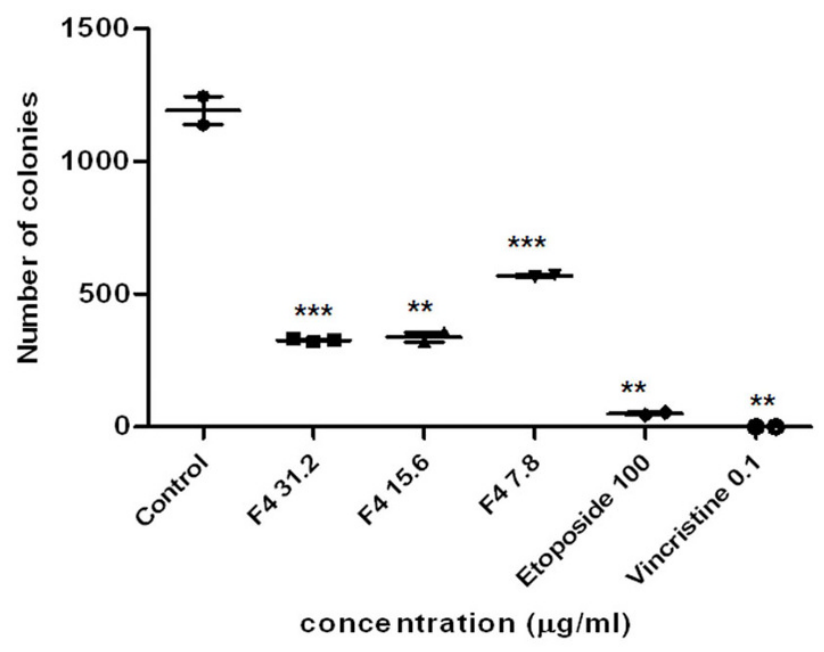

Figure 6

F4 fraction abrogates K562 erythroleukemic cells colony forming ability. $\mathrm{K} 562$ cells plated at $2.5 \times 10^{5}$ cells/ well were treated with ethanol $(0.2 \%)$, or F4 fraction (from 7.8 to $31.2 \mu \mathrm{g} / \mathrm{ml})$, or etoposide $(100 \mu \mathrm{g} / \mathrm{ml})$, or vincristine $(0.1 \mu \mathrm{g} / \mathrm{ml})$ for $24 \mathrm{~h}$. Afterwards, cells were stained with crystal violet $(0.4 \%$ in ethanol). Data represents number of colonies \pm SEM representing two independent experiments. $* * *$ p $<0.00$ I versus control (ethanol 0.2\%) Unpaired Student's $t$-test).

ATP synthase, $\mathrm{H}^{+}$transporting, mitochondrial F1 complex, beta subunit precursor, glyceraldehyde-3-phosphate dehydrogenase, glucosidase II, prostaglandin E synthase 3 (cytosolic), dihydropyrimidinase-like 2 variant); some were drastically down-regulated, while others were greatly up-regulated. Chaperone proteins (e.g., Hsp70, Hsp60, tumor rejection antigen (gp96), Hsp90, Hsp90alpha) were also down-regulated after F4 fraction treatment; these proteins are critical for cell survival and protection from stressful stimuli.

\section{Discussion}

Significant attained information from ethnopharmacological reports for our study is the Petiveria alliacea's antitumor and immunomodulatory reported activities. To date at a molecular level, there is a lack of scientific evidence to explain such activities. For example, a methanolic extract was unable to induce cytotoxicity on Hep G2 cells. Nonetheless, no specific reason was given for the lack activity in this case [25]. Several compounds isolated from Petiveria alliacea, such as astilbin and dibenzyl trisulphide have been demonstrated to induce apoptosis or influence cell cycle or affect actin dynamics $[20,26]$. The present study demonstrates that Petiveria alliacea's F4 fraction contains substances capable of inducing G2 arrest in a dose and time dependent manner (Fig. 5). The ability of F4 fraction to change cell morphology and induce G2 arrest was further investigated. Previous reports demonstrate that dibenzyl trisulphide (DTS), one of the sulfur compounds found in Petiveria alliacea, might be responsible for this dual activity [20]. DTS has been previously reported to exhibit potent immunomodulatory function, capable of increasing murine thymic weight along with up-regulation of parameters associated with the reticuloendothelial system, a system essential for molecules involved in immunomodulatory functions [23]. Mice exposed to lethal dose of $E$. coli were protected from death probably because an increase in phagocytic activity $[27,28]$. DTS has also been reported having anti-fungal activity in vitro [16], as well as insecticidal, acaricidal and insect repellent activities in vivo [29].

DTS causes reversible microtubule disassembly, which may be due to attenuation of the tyrosyl residues dephosphorylation of the MAP kinases (erk1/erk2) [20]. Along with the fact that MAP kinases are involved in development and apoptotic responses, this event suggests a molecular linkage between these two observations. Mixed-lineage kinase 3 (MLK-3, a kinase of the family controlling MAP kinases activity) inhibition, can cause mitotic arrest by a mechanism involving disruption of microtubule formation and spindle pole assembly [30]. The latter data indicates that Petiveria alliacea F4 fraction might inhibit MLK3.

Presence of apoptotic cells after treatment with F4 fraction clearly suggests that cell cycle arrest induces cell death (Fig. 5A). The F4 fraction from Petiveria alliacea did not cause mitochondrial membrane depolarization, suggesting that cell death is caused by mitochondrial independent mechanisms (Fig. 4A and 4B). Differentiation of cell death mechanisms, such as necrosis or apoptosis, become necessary since an inflammatory response after tissue injury might be different. The induction of an immune response in situ could be the consequence of equilibrium between apoptosis and subsequent necrotic death.

The types of compounds tentatively found in Petiveria alliacea's F4 fraction are sulfur compounds, flavonoids, flavonoid glycosides, coumarin, a monomethylated cyclo hexitol and a fatty acid. The sulfur compounds reported for Petiveria alliacea and probably present in F4 fraction are: thiobenzaldehyde S-oxide, dibenzyl sulfide, S-(2hydroxiethyl)-phenylmetanethiosulfinate, glutamyl-Sbenzyl cysteine and dibenzyltrisulfide (Fig. 1B y 1C). It is likely that these compounds are produced by petiverins (benzyl sulfoxides) degradation during the plant extraction process [31], and are associated with antitumor activity. Dibenzyl trisulfide, an immunomodulatory compound isolated from Petiveria $[20,21]$, is likely to be present in our fraction. Therefore, could be one of the compounds responsible for the biological activity present 
Table 2: Proteins down regulated by F4 Fraction

\begin{tabular}{|c|c|}
\hline Down regulated proteins & Accesion Num \\
\hline \multicolumn{2}{|l|}{ Translation } \\
\hline Asparaginyl-tRNA synthetase & NP_004530 \\
\hline BATI protein & BAF3I 287 \\
\hline CGI-74 protein & AAD34069 \\
\hline Dhx9 (DEAH) P-9, RNA Helicasa A (RHA)/DEAH (Asp-Glu-Ala-His) & NP_00I348 \\
\hline Eukariotic translation elongation factor I gamma & AAHI3918 \\
\hline Eukariotic translation elongation factor-2 (EF-2). & NP_001952 \\
\hline Eukaryotic initiation factor $4 \mathrm{~A}$ (elF-4A) & NP_00|407 \\
\hline Heparin-binding protein $\mathrm{HBpI} 5$ solo un articulo & AAP9726I \\
\hline Heterogeneous nuclear ribonucleoprotein $\mathrm{HI}$ & NP_0055II \\
\hline Heterogeneous nuclear ribonucleoprotein $\mathrm{U}$ isoform a (scaffold attachment factor- $\mathrm{A}$ ) & NP_II4032 \\
\hline Interleukin enhancer binding factor $3,90 \mathrm{Kda}$ & EAW 84137 \\
\hline Nucleolin & NP_005372 \\
\hline Nucleosome assembly protein I-like I & $N P \_631946$ \\
\hline Poly $(\mathrm{rC})$-binding protein 2 isoform b variant PCBP2 & NP_II4336 \\
\hline Small nuclear ribonucleoprotein Sm DI & CAEII897 \\
\hline Tryptophanyl-tRNA synthetase (IFP53) & CAA44450 \\
\hline Tu-transcription elongation factor. ET-I o EF-Tu & NP_0033I2 \\
\hline \multicolumn{2}{|l|}{ Transcription processing } \\
\hline CGI-74 & AAD34069 \\
\hline DEAD (Asp-Glu-Ala-His) box polypeptide 21 & NP_004719 \\
\hline DEAD (Asp-Glu-Ala-His) box polypeptide 9 & NP_00I348 \\
\hline \multicolumn{2}{|l|}{ Ribosomal Proteins } \\
\hline Ribosomal protein L4 & NP_000959 \\
\hline Ribosomal protein L5 & EAW̄73088 \\
\hline Ribosomal protein L7a & EAW88064 \\
\hline Ribosomal protein L8 & NP_000964 \\
\hline Ribosomal protein L9 & NP_000652 \\
\hline Ribosomal protein LIO & NP_006004 \\
\hline Ribosomal protein LIOa & NP_009035 \\
\hline Ribosomal protein LII & NP_000966 \\
\hline Ribosomal protein LI2 & BAD̄̄92708 \\
\hline Ribosomal protein LI3 & NP_150254 \\
\hline Ribosomal protein LI3a & AAQI3495 \\
\hline Ribosomal protein LI4 & NP_004964 \\
\hline Ribosomal protein LI8 & NP_000970 \\
\hline Ribosomal protein LI8a & XP_943475 \\
\hline Ribosomal protein LI9 & EAW 60568 \\
\hline Ribosomal protein L23 & NP_000969 \\
\hline Ribosomal protein L26 & NP_001087230 \\
\hline Ribosomal protein L27 & NP_000979 \\
\hline Ribosomal protein L27a & NP_00I083056 \\
\hline Ribosomal protein L28 & NP_000982 \\
\hline Ribosomal protein L3I & NP_000984 \\
\hline Ribosomal protein L32 & NP_000985 \\
\hline Ribosomal protein L36 & NP_378669 \\
\hline Ribosomal protein L37a & NP_000989 \\
\hline Ribosomal protein S2 & NP_002943 \\
\hline Ribosomal protein S4 & EAW71815 \\
\hline Ribosomal protein S5 & BAD 93040 \\
\hline Ribosomal protein S6 & NP_00100I \\
\hline Ribosomal protein $\$ 8$ & EAX07023 \\
\hline Ribosomal protein SII & NP_001006 \\
\hline Ribosomal protein SI2 & EAW 54624 \\
\hline Ribosomal protein SI3 & NP_001008 \\
\hline Ribosomal protein SI5a & EAW50259 \\
\hline Ribosomal protein SI8 & NP_00I087248 \\
\hline
\end{tabular}


Table 2: Proteins down regulated by F4 Fraction (Continued)

\begin{tabular}{lr}
\hline Ribosomal protein S19 & NP_001013 \\
Ribosomal protein S24 & EAW54624 \\
Ribosomal protein S25 & NP_00I019 \\
Ribosomal protein S27 & EAW91426 \\
Ribosomal protein P0 variant & BAD9629I
\end{tabular}

\section{Replication}

CSEI chromosome segregation I-like protein

NP_001307

ErbB3 (HER3) binding protein I

Nucleolin

Protein Kinase, DNA-activated, catalytic polypeptide isoform I

NP_006182

NP_005372

NP_008835

\section{Degradation Proteins}

26S proteasome subunit $\mathrm{p} 45$

BAA07919

Flap structure-specific endonuclease I

NP_004102

Fumarate hydratase, isoform CRA_b

EAW7009I

Histone cluster I, HId

NP_0053II

HMG-I

Hydroxysteroid (17-beta) dehydrogenase 10 isoform I

BAA09924

Mitochondrial acetoacetyl-CoA thiolase

NP_004484

BAA01 387

PSMC3 protein

AA107805

\section{Transporters}

Mitochondrial trifunctional protein, alpha subunit precursor

Prohibitin 2 (Phb2)

Solute carrier family 25 (SLC25A5 protein)

NP 000173

NP_009204

AAH68199

\section{Cytoskeleton}

Actin, gamma I propeptide

Adenylyl cyclase-associated protein

Chaperonin containing TCP-I (subunit $6 \mathrm{~A}$ and 7)

Dynein light chain I

F-actin capping protein alpha I

Kinesin

Lamin A/C, isoform CRA_C

Lamin B

Miller-Dieker lissencephaly protein

Myosin heavy polypeptide 9

Myosin, light polypeptide 6B, alkali, smooth muscle and non-muscle, isoform CRA_c

Plectin

t-complex polypeptide I (TCP-I)

Tubulin alpha 6

NP_001605

NP_006358

NP_006420

NP_003737

NP_006126

NP_0045I2

AAH005II

NP_005564

AAL34972

NP_002464

EAW96898

NP_958782

CAA37064

NP_II6093

\section{Signal Transduction}

RAB5C, member RAS oncogene family isoform b

NP_004574

Guanine nucleotide binding protein (G-protein)

EAW 53700

IQ Motif containing GTPase activating protein I

BAA06123

Prohibitin (PHB)

CAG46507

RAN member RAS oncogene familly

\section{Chaperones}

HSP70-prot 8

HSP60

Tumor rejection antigen (gP96) or Heat schock protein $90 \mathrm{Kda}$ beta

Heat shock protein $90 \mathrm{kDa}$ alpha (HSP90)

\section{Metabolism}

ACLY variant protein

BAE06II7

ATP synthase, $\mathrm{H}+$ transporting, mitochondrial FI complex, beta subunit precursor 
Table 2: Proteins down regulated by F4 Fraction (Continued)

\begin{tabular}{lc}
\hline Glucosidase II & CAA04006 \\
Glyceraldehyde-3-phosphate dehydrogenase & NP_002037 \\
Lactate dehydrogenase A & NP_005557 \\
Peroxiredoxin 6 & NP_004896 \\
Phosphoglicerate kinase (PGK) & NP_000282 \\
Phosphoglycerate dehydrogenase & NP_0066I4 \\
Prostaglandin E synthase 3 (cytosolic) & AAH03005 \\
Pyruvate Kinase, muscle isoform CRA_c & AAHI28II \\
Tumoral Antigen & P43358 \\
Melanoma-associated antigen 4 (MAGE 4 antigen) & \\
Calcium binding proteins & NP_00II45 \\
Annexin 5 & NP_001002858 \\
Annexine A2 isoform I & \\
\hline
\end{tabular}

Proteins from A375 human cells treated with F4 or ethanol (0.2\%) as negative control were digested, and the extracted peptides injected onto a I 100 Series HPLC-Chip Cube MS interface, and Agilent 6300 Series Ion Trap Chip-LC-MS/MS system (Agilent Technologies). Data are the proteins down regulated by $\mathrm{F} 4$ fraction treatment as judged by mass spectrometry.

Table 3: Proteins up regulated by F4 Fraction

\begin{tabular}{|c|c|}
\hline Up regulated Proteins & Accesion Number \\
\hline \multicolumn{2}{|l|}{ Translational Proteins } \\
\hline Alanyl t-RNA synthetase variant & BAD 96544 \\
\hline CDA02 (Eukaryotic translation initiation factor $2 \mathrm{~A}$ ) & AAKI4926 \\
\hline Eukaryotic translation initiation factor 2 , subunit I alpha, $35 \mathrm{kDa}$ & NP_001406 \\
\hline Eukaryotic translation initiation factor 3 subunit A, KIAA0I39 & BAĀ09488 \\
\hline GAI7 protein (eukaryotic translation initiation factor 3, subunit M) & NP_00635I \\
\hline GCNI general control of amino-acid synthesis I-like I, KIAA02I9 & BAAI3209 \\
\hline Leucyl-tRNA synthetase, cytoplasmic, KIAAI352 & BAA92590 \\
\hline Methionine adenosyltransferase II, alpha & NP_005902 \\
\hline Mitochondrial isoleucine tRNA synthetase & NP_060530 \\
\hline Prtl homolog, Eukaryotic translation initiation factor 3 subunit B & $\mathrm{AAB} 42010$ \\
\hline Synaptotagmin binding RNA interacting protein, SYNCRIP & AAH24283 \\
\hline \multicolumn{2}{|l|}{ Transcription processing } \\
\hline DNA-binding protein A (Cold shock domain-containing protein A) & PI6989 \\
\hline Heterogeneous nuclear ribonucleoprotein $M$ isoform a & NP_005959 \\
\hline Small nuclear ribonucleoprotein polypeptide $\mathrm{F}$ & NP_003086 \\
\hline Small nuclear ribonucleoprotein Sm DI & CAEII897 \\
\hline \multicolumn{2}{|l|}{ Ribosomal Proteins } \\
\hline Ribosomal protein SI5 & NP_001004 \\
\hline Ribosomal protein S9 & NP_001009 \\
\hline Ribosomal Protein S3A & NP_000996 \\
\hline \multicolumn{2}{|l|}{ Protein Degradation } \\
\hline Proteasa de Cisteina del Retículo (ER60) & BAAII 928 \\
\hline Proteasome 26S ATPase subunit I variant & BAD 96388 \\
\hline Proteasome $26 \mathrm{~S}$ ATPase subunit 2 & NP_002794 \\
\hline Proteasome $26 \mathrm{~S}$ non-ATPase subunit II variant & BAD 96916 \\
\hline Proteasome $26 \mathrm{~S}$ non-ATPase subunit 2 variant & BAD 93080 \\
\hline Putative ubiquitin-conjugating enzyme E2 D3-like protein & Q9NTTI \\
\hline SUMOI activating enzyme subunit I & NP_00549I \\
\hline Tripeptidyl peptidase II & $\mathrm{CAH} 72178$ \\
\hline Ubiquitin-Activating enzime EI & NP_003325 \\
\hline \multicolumn{2}{|l|}{ Transporters } \\
\hline Amino acid transporter EI6 & AAC61479 \\
\hline ATPase, $\mathrm{Ca}++$ transporting, cardiac muscle, slow twitch 2 isoform I & NP_733765 \\
\hline
\end{tabular}


Table 3: Proteins up regulated by F4 Fraction (Continued)

Coatomer protein complex subunit alpha isoform I (Cop I)

Exportin I

Karyopherin beta I, Importin subunit beta-I

SECI3-like I (S. cerevisiae), isoform CRA_b

Signal recognition particle $72 \mathrm{kDa}$

Solute carrier family 25 (mitochondrial carrier, Aralar), member 12

Stomatin

\section{Cytoskeleton}

Actin related protein $2 / 3$ complex subunit 2

ARP3 actin-related protein 3 homolog

Chaperonin containing TCPI-subunit 2 beta

Chaperonin containing TCPI-subunit 3 gamma

Destrin, isoform a

Dynactin I isoform I

Dynamin I-like, isoform CRA_c

Filamin A, FLJ00343

MYOIC variant protein (myosin-I beta)

T-complex protein I subunit epsilon, KIAA0098

Transgelin-2, KIAAOI 20

\section{Cell Cycle}

Alpha isoform of regulatory subunit A, protein phosphatase 2

Minichromosome maintenance complex component 6

Poly (ADP-ribose) polymerase family, member I

Regulator of chromosome condensation I, isoform CRA_c

Septin 9, KIAA099I

Signal Transduction

GTP-binding protein PTD004 isoform I

Phosphofructokinase, platelet, isoform CRA a

Protein kinase $\mathrm{C}$ inhibitor protein I, YWHAZ

NP_037473

EAW86495

AAH5 1814

\section{Chaperones}

Calnexin precursor

NP_001737

Nucleophosmin

Oxygen regulated protein precursor

TNF receptor-associated protein I variant

\section{Metabolism}

5-aminoimidazole-4-carboxamide ribonucleotide formyltransferase

NP_005906

NP 001609

EAX07692

BAA76835

Acyl-CoA synthetase long-chain family 3

Aldehyde dehydrogenase 18 family, member AI

Alkylglycerone phosphate synthase, isoform CRA_b

Carbamoylphosphate synthetase 2/aspartate transcarbamylase/dihydroorotase

Dolichyl-diphosphooligosaccharide-protein glycosyltransferase

Enoyl Coenzyme A hydratase

Glucosamine-fructose-6-phosphate aminotransferase (GFAT I)

HMTI hnRNP methyltransferase-like 2 isoform I

AAW67757

NP 006380

BAD 93042

Human rab GD

Hydroxyacyl-Coenzyme A dehydrogenase

Inosine monophosphate dehydrogenase 2, hCG2002013

Ornithine aminotransferase precursor

Phosphogluconate dehydrogenase

Phosphoribosyl pyrophosphate synthetase 2, PRPS2

RPN2

S-adenosylhomocysteine hydrolase
NP_004035

NP_97625I

CAII 6766

EAXI 1058

NP 004332

CAH73476

AAH08906

Q06210

NP_001527

BAA03095

AAHI 4572

EAW64946

NP 000265

NP 002622

NP_002756

CAG33180

NP 000678

Proteins from A375 human cells treated with F4 or ethanol $(0.2 \%)$ as negative control were digested, and the extracted peptides injected onto a I 100 Series HPLC-Chip Cube MS interface, and Agilent 6300 Series Ion Trap Chip-LC-MS/MS system (Agilent Technologies). Data are the proteins up regulated by $\mathrm{F} 4$ fraction treatment as judged by mass spectrometry. 
in F4 fraction. Pinitol, a monomethylated cyclohexitol reported in Petiveria alliacea and possibly present in our fraction, has been reported to exhibit anti-inflammatory properties [32], possibly acting on dendritic cells [33]. Myricitrin, a flavonoid glycoside probably present in F4 fraction, has been reported to have analgesic, anti-inflammatory and antinociceptive properties [34]. Coumarin, another compound possibly found in the $\mathrm{F} 4$ fraction is reported to exhibit anti-tumor activity in prostate cancer models [35], and anti-inflammatory activities [36]. Other compounds possibly present in F4 fraction, includes senfol (1,2 diisothiocyanato ethane) , 3,5 diphenyltritiolan, 4 ethyl petiveral, 5-O-methyl leridol and lignoceric acid have no literature reports related to anti-tumoral activity.

Down-regulation of cytoskeleton proteins detected by mass spectrometric analysis is consistent with the cytoskeleton disruption observed by fluorescent microscopy. Moreover, changes in the concentration of proteins involved in translation and transduction processes, as well as those involved in cellular metabolism, could explain the decrease of tumor cells clonogenic ability, as well as the anti-tumor activity of Petiveria alliacea. Currently, we are evaluating the coding genes for these proteins in order to determine if the changes are at the transcriptional level or whether the proteomic results are a consequence of differential management of the existing proteins in the tumor cells. The mechanism by which tumor cells undergo death should be determined. Our results indicate that there is DNA fragmentation; however, it is possible that oxidative stress, metabolic changes, necrosis or senescence are also ways by which tumor cells may undergo death. In fact, necrotic death can provide the necessary danger signals to induce dendritic cells activation, giving anti-tumoral protective immune response [37]; although other mechanisms can be implied in this antigen transfer [38,39]. Induction of an effective immune response is unknown, but possibly Petiveria alliacea F4 fraction, can act as Sho-Saiko-to, or Juzen-taiho-to $[40,41]$, inducing reduction of primary tumors, metastasis, and generating a specific CD8+ CTL responses. Mechanisms implied in the process are unknown. However, it is critical to understand and elucidate the molecular mechanisms before the plant fraction can be used in the design of effective cancer drug therapeutics.

\section{Conclusion}

In conclusion, our study demonstrates that Petiveria alliacea's F4 fraction, exhibits multiple anti-tumoral activities against human (K562, A375) and mouse (Mel Rel) tumor cells. F4 fraction exerts G2 cell cycle arrest, induces actin cytoskeleton reorganization, affects cell morphology, causes DNA fragmentation and decreases clonogenicity. Furthermore, our findings indicate that F4 fraction may use multiple molecular targets to exert its antitumor activity.

\section{Abbreviations used}

EtOH: ethanol; EtOAc: ethyl acetate; Hsp70: seventy kiloDalton heat shock protein; MeOH: methanol; MLK-3: mixed-lineage kinase 3; MTT: 3-(4,5-dimethylthiazol-2yl)-2,5-diphenyltetrazolium bromide; PBMC: peripheral blood mononuclear cells; PAF: paraformaldehyde; PBS: phosphate buffer saline.

\section{Competing interests}

The authors declare that they have no competing interests.

\section{Authors' contributions}

The present work was conceived, directed and coordinated by SF helped by AA. Biological assays, cell line maintenance, viability tests, cell cycle and cytoskeleton analysis, DAPI DNA fragmentation test and protein expression analysis by CU. CC, performed the preparation and characterization of the plant extracts by de-replicacion, DC, performed mitochondrial membrane depolarization tests and AA, performed clonogenicity tests. PK, performed protein LC-MS/MS sample preparation and analysis by Spectra Mill bioinformatics software. All authors have read the manuscript and agree to its contents.

\section{Acknowledgements}

Grant support: The Instituto Colombiano para el Desarrollo de la Ciencia y la Tecnología "Francisco Jose de Caldas" (COLCIENCIAS) Bogotá, Colombia. Grant number I203-05-14660 (S. Fiorentino). US National Institutes of Health grant ROICA91889, institutional support from Scott \& White Memorial Hospital and Clinic, the Texas A\&M Health Science Center College of Medicine, the Central Texas Veterans Health Administration and an Endowment from the Cain Foundation (A. Asea), and we thank Lei Shi, Vadiraja B and Preethi Rao for expert technical assistance.

\section{References}

I. El-Deiry WS: Meeting report: The international conference on tumor progression and therapeutic resistance. Cancer Res 2005, 65:4475-84.

2. Johnstone RW, Ruefli AA, Lowe SW: Apoptosis: a link between cancer genetics and chemotherapy. Cell 2002, 108:| 53-64.

3. Bellamy WT: P-glycoproteins and multidrug resistance. Annu Rev Pharmacol Toxicol 1996, 36:161-83.

4. Gottesman MM, Pastan I: Biochemistry of multidrug resistance mediated by the multidrug transporter. Annu Rev Biochem 1993, 62:385-427.

5. Gouaze V, Yu JY, Bleicher RJ, Han TY, Liu YY, Wang H, Gottesman MM, Bitterman A, Giuliano AE, Cabot MC: Overexpression of glucosylceramide synthase and P-glycoprotein in cancer cells selected for resistance to natural product chemotherapy. Mol Cancer Ther 2004, 3:633-9.

6. Lopes-Martins RA, Pegoraro DH, Woisky R, Penna SC, Sertie JA: The anti-inflammatory and analgesic effects of a crude extract of Petiveria alliacea L. (Phytolaccaceae). Phytomedicine 2002, 9:245-8.

7. Morales C, Gomez-Serranillos MP, Iglesias I, Villar AM, Cáceres A: Preliminary screening of five ethnomedicinal plants of Guatemala. Farmaco 2001, 56:523-526.

8. di Stasi LC, Costa M, Mendacolli SL, Kirizawa M, Gomes C, Trolin G: Screening in mice of some medicinal plants used for analge- 
sic purposes in the state of Sao Paulo. J Ethnopharmacol 1988, 24:205-II.

9. de Lima TC, Morato GS, Takahashi RN: Evaluation of antinociceptive effect of Petiveria alliacea (Guine) in animals. Mem Inst Oswaldo Cruz 199I, 86(Suppl 2): I53-8.

10. De Sousa PJ, JR DA, Afonso AM: Guiné: erva medicinal ou tóxica. Ciênc Cult 1987, 39:645-646.

II. Bernal HYC, Enrique Jaime: Especies Vegetales promisorias de los países del convenio Andrés Bello, Bogotá: Secretaría ejecutiva del Convenio Andrés Bello. SECAB edn 1998.

12. Gupta M: Petiveria alliacea in 270 plantas medicinales iberoamericanas, Presencia ed edn 1995

13. Garcia B: Flora medicinal de colombia, Imprenta nacional ed. Bogotá edn. Bogotá 1974.

14. De Sousa JR, Demuner AJ, Pinheiro JA, Breitmaier E, Cassels BK: Dibenzyl trisulphide and trans-N-methyl-4-methoxyproline from Petiveria alliacea. Phytochemistry 1990, 29:3653-3655.

15. Delle-Monache F, Menichini F, Cuca LE: Petiveria alliacea: II. Further Flavonoids and Triterpenes. Gazzeta Chimica Italiana 1996, 1 26:275-278.

16. Delle-Monache F, Cuca LE: 6-C-formyl and 6-C hidroxymethyl flavonones from Petiveria alliacea. Phytochemistry 1992, 3I:248I-2482.

17. Kubec R, Musah RA: Cysteine sulfoxide derivatives in Petiveria alliacea. Phytochemistry 200I, 58:98I-5.

18. Kubec R, Kim S, Musah RA: S-Substituted cysteine derivatives and thiosulfinate formation in Petiveria alliacea-part II. Phytochemistry 2002, 61:675-80.

19. Kubec R, Musah RA: gamma-Glutamyl dipeptides in Petiveria alliacea. Phytochemistry 2005, 66:2494-7.

20. Rosner H, Williams LA, Jung A, Kraus W: Disassembly of microtubules and inhibition of neurite outgrowth, neuroblastoma cell proliferation, and MAP kinase tyrosine dephosphorylation by dibenzyl trisulphide. Biochim Biophys Acta 200I, 1540:166-77.

21. Williams LA, Rosner H, Levy HG, Barton EN: A critical review of the therapeutic potential of dibenzyl trisulphide isolated from Petiveria alliacea L (guinea hen weed, anamu). West Indian Med J 2007, 56: 17-2I.

22. Benevides PJ, Young MC, Giesbrecht AM, Roque NF, Bolzani VS Antifungal polysulphides from Petiveria alliacea $\mathrm{L}$. Phytochemistry 200I, 57:743-7.

23. Williamson EM: Synergy and other interactions in phytomedicines. Phytomedicine 200I, 8:40I-9.

24. Ulrich-Merzenich $G$, Zeitler $H$, Jobst $D$, Panek $D$, Vetter $H$, Wagner $\mathrm{H}$ : Application of the "-Omic-" technologies in phytomedicine. Phytomedicine 2007, 14:70-82.

25. Ruffa MJ, Ferraro G, Wagner ML, Calcagno ML, Campos RH, Cavallaro L: Cytotoxic effect of Argentine medicinal plant extracts on human hepatocellular carcinoma cell line. J Ethnopharmacol 2002, 79:335-9.

26. Yan R, Xu Q: Astilbin selectively facilitates the apoptosis of interleukin-2-dependent phytohemagglutinin-activated Jurkat cells. Pharmacol Res 200I, 44:I35-9.

27. Delaveau P, Lallouette P, Tessier AM: [Stimulation of the phagocytic activity of R.E.S. by plant extracts (author's transl)]. Planta Med 1980, 40:49-54.

28. Wagner HPA: Immunostimulatory drugs of fungi and higher plants. London 1985.

29. Johnson L, Williams LAD, Roberts E: An Insecticidal and Acaricidal Polysulfide metabolite from the Roots of Petiveria alliacea. Pesticide Science 1997, 50:228-232.

30. Cha H, Dangi S, Machamer CE, Shapiro P: Inhibition of mixed-lineage kinase (MLK) activity during G2-phase disrupts microtubule formation and mitotic progression in HeLa cells. Cell Signal 2006, 18:93-104.

31. Kubec R, Kim S, Musah RA: The lachrymatory principle of Petiveria alliacea. Phytochemistry 2003, 63:37-40.

32. Singh RK, Pandey BL, Tripathi M, Pandey VB: Anti-inflammatory effect of (+)-pinitol. Fitoterapia 200I, 72:168-70.

33. Lee JS, Jung ID, Jeong YI, Lee CM, Shin YK, Lee SY, Suh DS, Yoon MS, Lee KS, Choi YH, et al.: D-pinitol inhibits ThI polarization via the suppression of dendritic cells. Int Immunopharmacol 2007 7:791-804.

34. Meotti FC, Fachinetto R, Maffi LC, Missau FC, Pizzolatti MG, Rocha JB, Santos AR: Antinociceptive action of myricitrin: involve- ment of the K+ and Ca2+ channels. Eur J Pharmacol 2007, 567:198-205.

35. Maucher A, Kager M, von Angerer E: Evaluation of the antitumour activity of coumarin in prostate cancer models. J Cancer Res Clin Oncol 1993, I1 9:150-4.

36. Shimizu M, Shogawa H, Matsuzawa T, Yonezawa S, Hayashi T, Arisawa M, Suzuki S, Yoshizaki M, Morita N, Ferro E, et al.: Anti-inflammatory constituents of topically applied crude drugs. IV. Constituents and anti-inflammatory effect of Paraguayan crude drug "alhucema" (Lavandula latifolia Vill.). Chem Pharm Bull (Tokyo) 1990, 38:2283-4.

37. Wells $A D$, Malkovsky M: Heat shock proteins, tumor immunogenicity and antigen presentation: an integrated view. Immunol Today 2000, $21: 129-32$

38. Fiorentino S, Barreto A, Castañeda D, Cifuentes C: Anti-tumor response and heat shock proteins (HSP): a friend or foe relationship Netherlands: Springer edn; 2007.

39. Asea A: Mechanisms of HSP72 release. J Biosci 2007, 32:579-84

40. Kato M, Liu W, Yi H, Asai N, Hayakawa A, Kozaki K, Takahashi M, Nakashima I: The herbal medicine Sho-saiko-to inhibits growth and metastasis of malignant melanoma primarily developed in ret-transgenic mice. J Invest Dermatol 1998, I I I :640-4.

4I. Dai Y, Kato M, Takeda K, Kawamoto Y, Akhand AA, Hossain K, Suzuki $H$, Nakashima I: T-cell-immunity-based inhibitory effects of orally administered herbal medicine juzen-taiho-to on the growth of primarily developed melanocytic tumors in RETtransgenic mice. J Invest Dermatol 200I, I I 7:694-70I.

\section{Pre-publication history}

The pre-publication history for this paper can be accessed here:

http://www.biomedcentral.com/1472-6882/8/60/prepub

Publish with BioMed Central and every scientist can read your work free of charge

"BioMed Central will be the most significant development for disseminating the results of biomedical research in our lifetime. "

Sir Paul Nurse, Cancer Research UK

Your research papers will be:

- available free of charge to the entire biomedical community

- peer reviewed and published immediately upon acceptance

- cited in PubMed and archived on PubMed Central

- yours - you keep the copyright 